\title{
Psilolintonum lineatum (Linton, 1928) (Echinostomatoidea: Psilostomidae) re-allocated to Podocotyle (Allocreadioidea: Opecoelidae) on the basis of a re-examination of the type material
}

\author{
Aneta Kostadinova \\ Department of Biodiversity, Central Laboratory of General Ecology, Bulgarian Academy of Sciences, 2 Gagarin Street, 1113 \\ Sofia, Bulgaria
}

Key words: Digenea, Opecoelidae, Psilostomidae, Psilostomum lineatum, Psilolintonum, Podocotyle reflexa, morphology, synonymy

\begin{abstract}
The type-material of Psilostomum lineatum Linton, 1928 was re-examined and identified as Podocotyle reflexa (Creplin, 1825). This re-allocation of the type and only species invalidates the genus Psilolintonum that is now considered a synonym of Podocotyle.
\end{abstract}

Linton (1928) described Psilostomum lineatum Linton, 1928 on the basis of two specimens from Larus argentatus collected on the Atlantic coast of the USA (Woods Hole) and assigned the new species to the genus Psilostomum Looss, 1899 without comment. Oshmarin (1964) while erecting a new genus within the Psilostomidae Looss, 1900, Psilolecithum Oshmarin, 1964 for the new species $P$. longorchum Oshmarin, 1964, made comment on $P$. lineatum. He indicated that this species is rather different from the type and all other species of the genus Psilostomum in its strongly elongate body, the presence of an oesophagus, and especially in the peculiar distribution of the vitelline fields which are confluent posterior to the testes but also fill the intertesticular space. He noted that the latter feature is unique within the Psilostomidae and occasionally observed in the closely related family Echinostomatidae Looss, 1899 and erected a new genus, Psilolintonum Oshmarin, 1964 for P. lineatum.

This paper presents a redescription of the typematerial of $P$. lineatum. Based on this redescription $P$. lineatum is now re-allocated to the genus Podocotyle Dujardin, 1845 (Allocreadioidea: Opecoelidae).

\section{RESULTS}

Family O p e c o e 1 i d a e Ozaki, 1925

Subfamily P 1 a g i o p o r in a e Manter, 1947

Genus Podocotyle Dujardin, 1845

Podocotyle reflexa (Creplin, 1825)

Figs. 1, 2

Syn. Psilostomum lineatum Linton, 1928; Psilolintonum lineatum (Linton, 1928) Oshmarin, 1964.

Material studied. Holotype and paratype of Psilostomum lineatum Linton, 1928 collected in Woods Hole (USA) from Larus argentatus deposited in the U.S. National Animal Parasite Collection (USNPC 007917.00).
Description (measurements in micrometres). Body very elongate, narrow, with almost parallel margins, $2694-5322 \times 545-551$; maximum width $10.2 \%$ of length. Tegument unarmed. Oral sucker subterminal, subglobular, 178-184 × 130-195. Ventral sucker muscular, transversely oval, 266-308 × 326-332; aperture slit-like. Sucker ratio $1: 1.7-1.8$. Forebody 456 long (paratype), $8.6 \%$ of body length. Prepharynx indistinct. Pharynx elongate-oval, $130 \times 92-101$. Oral sucker/pharynx width ratio $1: 1.9$. Oesophagus short. Caeca blind, reach close to posterior extremity.

Testes two, tandem, separated by space 65-95 long; large, elongate-oval, smooth or somewhat irregular (paratype); in mid-hindbody. Anterior testis 426-497 $\times$ 284-320; posterior testis 480-533 $\times$ 349-385. Cirrus-sac very long, 1036; extending well into hindbody, 444 posterior to posterior margin of ventral sucker. Posterior part widened, $385 \times 124$, containing voluminous (coiled?) internal seminal vesicle; anterior part longer, narrowed-tubular, $651 \times 47$. Pars prostatica distinct, tubular. Ejaculatory duct as long as pars prostatica, opens into base of a small genital atrium. Cirrus not observed. Genital pore slightly sinistral at level of intestinal bifurcation.

Ovary just pre-testicular, submedian, campaniform trilobed (one anterior and three posterior lobes), length of longitudinal axis 254-342, maximum width 228-301. Oviduct leaves from anterior lobe of ovary. Canalicular seminal receptacle large, voluminous, filled with spermatozoa, 248-307 × 152-255; anterodorsal to ovary, partly overlapping its anterior lobe (holotype) or entirely dorsal to ovary and contiguous with anterior testis (paratype). Mehlis' gland diffuse, immediately anterior to ovary, $73 \times 88$. Laurer's canal present, contains sperm, runs sinistrally to ovary and opens sinistro-dorsal to the base of its anterior lobe. 


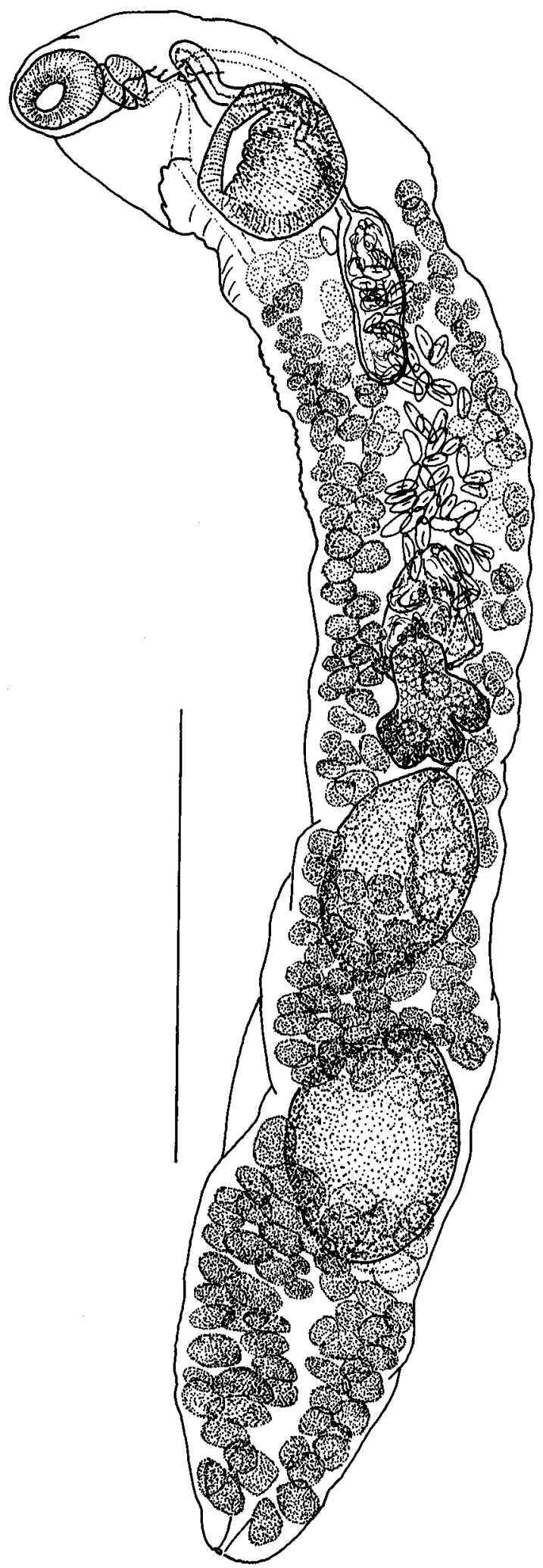

Fig. 1. Podocotyle reflexa (holotype of Psilostomum lineatum Linton, 1928, USNPC 007917.00). Ventral view. Scale bar $=$ $1000 \mu \mathrm{m}$.

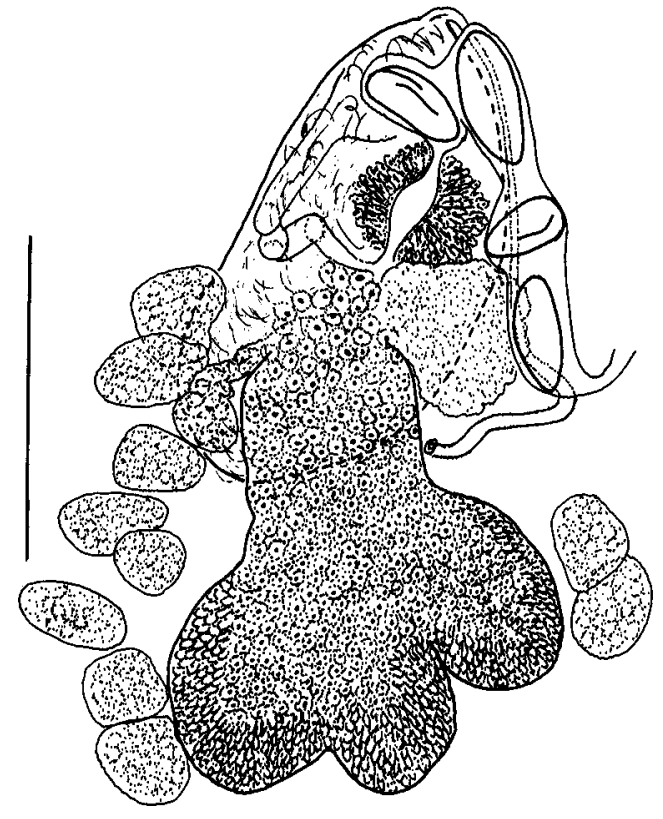

Fig. 2. Podocotyle reflexa (holotype of Psilostomum lineatum Linton, 1928, USNPC 007917.00). Detail of female reproductive system. Scale bar $=200 \mu \mathrm{m}$.

Uterus pre-ovarian, eggs relatively numerous, $67-76$ $\times$ 33-44. Metraterm long, opens to genital atrium dextrally to male duct. Vitellarium follicular; follicles large, in two lateral fields between posterior margin of ventral sucker and posterior extremity; fields interrupted at mid-level of each testis but numerous follicles encroaching between testes.

Excretory vesicle not observed, pore dorso-subterminal.

\section{DISCUSSION}

In the original description of Psilostomum lineatum Linton (1928) noted the sinistral position of the genital pore, described the ovary as "somewhat pestle-shape" and stated that "there appears to be a seminal receptacle near the anterior edge of the ovary". Odhner (1928) made a short comment that this form resembles a member of the genus Podocotyle, P. olssoni Odhner, 1905. My re-examination of the types confirms these observations and strongly suggests that the material described as P. lineatum by Linton (1928) belongs to the plagioporine genus Podocotyle (sensu stricto) on the basis of the presence of a large canalicular seminal receptacle, the characteristic shape of ovary (campaniform trilobed), the structure of terminal genitalia, and the specific distribution of the vitelline fields which fill most of the hindbody laterally but are distinctly interrupted at the level of the testes. 
All these observations indicate that the two specimens found by Linton in L. argentatus and identified as $P$. lineatum may have originated from a marine teleost eaten by the gull. It is worth mentioning that another new species described on material from the same sample of L. argentatus and assigned by Linton (1928) to the genus Psilostomum, Psilostomum plicitum Linton, 1928, was found to represent in fact a fish parasite, i.e. Bianium plicitum (see Stunkard 1931).

The material described by Linton (1928) as $P$. lineatum shares the characteristic elongate shape of body and long cirrus-sac which extends well into hindbody, with nine other Podocotyle spp. included by Bray and Campbell (1996) in their conception of this genus, namely $P$. angulata (Dujardin, 1845), $P$. boneti Caballero et Caballero, 1970, P. enophrysi Park, 1937, $P$. radifistuli (Acena, 1941), P. reflexa (Creplin, 1825), P. scorpenae (Rudolphi, 1819), P. sinusacca Ching, 1960, P. temensis Fischthal et Thomas, 1970, and $P$. theragae (Lloyd, 1938).

However, comparisons based on additional morphological features which proved to be important for species discrimination (see Bray and Campbell 1996) such as the anterior extent of vitellarium and the shape of the ovary and testes, shorten this list to a single species, $P$. reflexa (syn. P. olssoni, see Bray and Campbell 1996). Morphologically Linton's specimens agree well with the descriptions of $P$. reflexa by Odhner (1905) and Miller (1941) as well as with the recent data on this species (Køie 1981, Gibson and Bray 1982). Therefore, the material misidentified by Linton (1928) as Psilostomum lineatum should be assigned to Podocotyle reflexa. This re-allocation of the type and only species invalidates the genus Psilolintonum that is now considered a synonym of Podocotyle.

Acknowledgements. This study was carried during the tenure by the author of a NATO/Royal Society/Foreign \& Commonwealth Office postdoctoral research fellowship at the Natural History Museum, London. I gratefully acknowledge Dr. J.R. Lichtenfels, USDA, ARS, Beltsville, for the loan of specimens.

\section{REFERENCES}

BRAY R.A., CAMPBELL R.A. 1996: New plagioporines (Digenea: Opecoelidae) from deep-sea fishes of the North Atlantic Ocean. Syst. Parasitol. 33: 101-113.

GIBSON D.I., BRAY R.A. 1982: A study and reorganization of Plagioporus Stafford, 1904 (Digenea: Opecoelidae and related genera, with special reference to forms from European Atlantic waters. J. Nat. Hist. 16: 529-559.

KØIE M. 1981: On the morphology and life-history of Podocotyle reflexa (Creplin, 1825) Odhner, 1905 (Trematoda, Opecoelidae). Ophelia 20: 17-43.

LINTON E. 1928: Notes on trematode parasites of birds. Proc. U. S. Nat. Mus. 73: 1-36, 11 plts.
MILLER M.J. 1941: A critical study of Stafford's report on 'Trematodes of Canadian fishes' based on his trematode collection. Can. J. Res. 19: 28-52.

ODHNER T. 1905: Trematoden des arktischen Gebietes. Fauna Arctica 4: 289-372.

ODHNER T. 1928: Weitere Trematoden mit Anus. Ark. Zool. 20 B (2): 1-6.

OSHMARIN P.G. 1964: Some new to science genera and species of trematodes from birds of Vietnam. Zool. Zh. 43: 652-661. (In Russian.)

STUNKARD H.W. 1931: Further observations on the occurrence of anal openings in digenetic trematodes. $\mathrm{Z}$. Parasitenkd. 3: 713-725.

Accepted 17 October 2000 